\title{
Radiosensitization with Chemotherapeutic Agents and Hyperthermia: Effects on Linear-quadratic Parameters of Radiation Cell Survival Curves
} Nicolaas A.P. Franken ${ }^{1 *}$, Suzanne Hovingh' ${ }^{1}$, Hans Rodermond ${ }^{1}$, Lukas Stalpers ${ }^{1}$, Gerrit W. Barendsen ${ }^{1,2}$ and Johannes Crezee ${ }^{1}$

${ }^{1}$ Department of Radiation Oncology, Laboratory for Experimental Oncology and Radiobiology (LEXOR), Centre of Experimental Molecular Medicine, Academic Medical Centre, University of Amsterdam

${ }^{2}$ Department of Cell Biology and Histology, Centre for Microscopic Research, Academic Medical Centre, University of Amsterdam

\begin{abstract}
The radio-sensitizing effects of several chemotherapeutic agents and hyperthermia have been investigated in several animal and human cell culture systems. Cells are first treated with Cisplatin, Gemcitabine, Halogenated pyrimidines or hyperthermia and thereafter irradiated with different dose of radiation up to $8 \mathrm{~Gy}$. After treatment the clonogenic survival was determined and from the survival curves the values of the linear and quadratic parameters were determined using the formula $S(D) / S(O)=\exp -\left(\alpha D+\beta D^{2}\right)$.
\end{abstract}

An increase in the value of the linear parameter, $\alpha$, was observed in most cases, which corresponds to an enhanced (potentially) direct lethal damage (PLD) at low doses. The quadratic parameter $\beta$, which is assumed to depend on the interaction of sublethal lesions (SLD), was rarely affected. Furthermore, it appeared that more radioresistant cell lines were more sensitised than the radiosensitive lines. Furthermore it can be concluded that radiosensitization is also dependent on cell cycle stage like plateau or exponentially growing phase or post treatment plating conditions.

\section{Introduction}

The radiosensitisation effects of chemotherapeutic agents and hyperthermia have been investigated in mammalian normal and cancer cell systems growing in vitro with respect to the linear quadratic parameters of dose-survival curve [1]. These treatment modalities are currently exploited in the clinic. The studies on the different human tumour cell lines show that a synergistic interaction can be obtained between chemotherapy, hyperthermia and radiation and that this interaction is more likely to occur in cell lines which are relatively sensitive to chemotherapy. The influence of modifying agents on radiation dose survival curves can adequately be analysed with the use of the linear-quadratic model: $S(D) / S(O)=\exp -\left(\alpha D+\beta D^{2}\right)$. The linear parameter, $\alpha$, represents lethal damage from single particle events and describes the low dose area while the quadratic parameter, $\beta$, indicating sub lethal damage (SLD) dominates the effectiveness in the high dose region [2-5]. The radiation dose survival curves have been obtained by carrying out clonogenic assays and values of the linear and quadratic parameters have been calculated [6].

The linear-quadratic model is based on well accepted biophysical concepts, involving the assumption that lethal damage can be induced by single-particle tracks and by interaction of damage from multiple particles. The LQ-model does not have a current biological basis. However, it has been found to describe the low-dose region of the survival curves up to 6 Gy rather accurately. Furthermore the LQmodel has been shown to describe adequately dose fractionation effects for normal tissue tolerance and for experimental tumours. The LQmodel has also the advantage that it requires only two parameters to describe radiation dose-survival curves. It allows the separate analysis of changes in effectiveness in the low dose range, mainly determined by the linear term and in the high dose range determined mainly by the quadratic term [7,8]. An additional advantage of the LQ model is that its parameters can be discussed in terms of specific mechanisms of cell inactivation by radiation $[2,3]$

\section{Materials and Methods}

\section{Cell cultures}

Several different cell lines have been used in the studies. The human squamous lung carcinoma cell line SW-1573 was grown as a monolayer in L-15 medium (Invitrogen, Breda, The Netherlands) supplemented with $10 \%$ heat-inactivated fetal bovine serum (FBS) and penicillin, streptomycin and glutamine at $37^{\circ} \mathrm{C}$ without additional $\mathrm{CO}_{2}$, The human ovarian carcinoma cell lines A2780 and its dFdC-resistant variant AG6000 were grown as monolayers in DMEM (Invitrogen) supplemented with $5 \%$ heat-inactivated FBS and with penicillin, streptomycin and glutamine at $37^{\circ} \mathrm{C}$ at $10 \% \mathrm{CO}_{2}$. The doubling time of the human cell lines in exponential growth is $22-24 \mathrm{~h}$.

V79 (hamster fibroblast cells), RUCII (Rat urether carcinoma) and R1 (Rat rhabdomyosarcoma) were grown as monolayers in minimal essential medium (Invitrogen) supplemented with 10\% foetal bovine serum, glutamine and penicillin at $37^{\circ} \mathrm{C}$ at $2 \% \mathrm{CO} 2$ in exponentially growing - and in plateau-phase. The doubling time of these cells is about $14 \mathrm{~h}$.

${ }^{*}$ Corresponding author: Nicolaas A.P. Franken, Department of Radiation Oncology, Laboratory for Experimental Oncology and Radiobiology (LEXOR), Centre of Experimental Molecular Medicine, Academic Medical Centre, University of Amsterdam P.O.Box 22700, 1100 DE Amsterdam, The Netherlands, E-mail n.a.franken@amc.uva.nl

Received November 01, 2011; Accepted December 05, 2011; Published December 07, 2011

Citation: Franken NAP, Hovingh S, Rodermond H, Stalpers L, Barendsen GW et al. (2011) Radiosensitization with Chemotherapeutic Agents and Hyperthermia: Effects on Linear-quadratic Parameters of Radiation Cell Survival Curves. J Cancer Sci Ther S5:002. doi:10.4172/1948-5956.S5-002

Copyright: (c) 2011 Franken NAP, et al. This is an open-access article distributed under the terms of the Creative Commons Attribution License, which permits unrestricted use, distribution, and reproduction in any medium, provided the original author and source are credited. 
Citation: Franken NAP, Hovingh S, Rodermond H, Stalpers L, Barendsen GW, et al. (2011) Radiosensitization with Chemotherapeutic Agents and Hyperthermia: Effects on Linear-quadratic Parameters of Radiation Cell Survival Curves. J Cancer Sci Ther S5:002. doi:10.4172/19485956.S5-002

Page 2 of 10

\section{Chemicals}

Platosin ${ }^{\bullet}$ (cis-diamminedichloroplatinum II, cDDP, cisplatin) was provided by Pharmachemie (Haarlem, The Netherlands). Gemzar ${ }^{\circ}$ (Gemcitabine, 2',2'-difluorodeoxycytidine, dFdC) was provided by Eli Lilly inc. (Indianapolis, IN, USA). All other chemicals were of analytical grade and commercially available. For chemo-therapeutically induced radio-sensitizing experiments cells were incubated with: 1) Medium containing cisplatin at a concentration of 1 or $5 \mu \mathrm{M}$ for $1 \mathrm{~h}$ before irradiation or continuously (In this case cisplatin was present during the clonogenic assay). 2) Gemcitabine at a concentration of 10, 50 or $100 \mathrm{nM}$, which was added 24 hours before irradiation. Before the start of irradiation medium containing gemcitabine was removed, cells were washed two times with PBS and fresh medium was added. 3) Medium with Iodo-deoxyUridine (IdUrd). For these experiments cells were incubated for $72 \mathrm{~h}$ with 0 or $4 \mu \mathrm{M}$ of IdUrd and $2.5 \mu \mathrm{M}$ thymidine was added to mimic the average level of thymidine in rodent plasma.

\section{Hyperthermia}

Hyperthermia was carried out in thermostatically regulated waterbath at 41 or $43^{\circ} \mathrm{C}$ for $60 \mathrm{~min}$.

The atmosphere of the waterbath was adjustable by a connection with air and CO2 supplies. Hyperthermia treatment was performed directly before the irradiation.

\section{Irradiation}

Irradiations were performed with single doses of $\gamma$-rays from a ${ }^{137} \mathrm{Cs}$ source at a dose rate of $0.7 \mathrm{~Gy} / \mathrm{min}$.

\section{Clonogenic assay for radiosensitivity}

After treatment, the cells were trypsinized directly (ip) or 24 after irradiation (dp) and replated in appropriate dilutions in 6-well macroplates (6). Eight to ten days after inoculation colonies were fixed in $6 \%$ glutaraldehyde and stained with $0.05 \%$ crystalviolet. Colonies of 50 cells or more were scored as originating from a single clonogenic cell. Surviving fractions $(S(D) / S(0)$ ) after dose (D) were corrected for the toxicity of $\mathrm{dFdC}$ alone $(\mathrm{S}(0))$ and survival curves were analyzed using SPSS (Chicago, IL, USA) statistical software by means of a fit of the data by a weighted, stratified, linear regression, according to the linear-quadratic formula: $S(D) / S(O)=\exp -\left(\alpha D+\beta D^{2}\right)$.

\section{Cisplatin}

Cisplatin is a widely used anti-cancer drug, often combined with radiotherapy [9]. Chemo-radiation application based on cisplatin has now become the standard treatment for, among others, locally advanced cervical carcinoma [10] and locally advanced non-small cell lung cancer (NSCLC) [11]. There have been many studies on the radiation sensitizing effect of cisplatin, but results vary from a clear cisplatin-induced radiosensitization [12-15] to only an additive effect on cell survival [16]. Cisplatin and radiation have in common that their cellular target is DNA [17].

Cisplatin causes DNA damage by the formation of inter- and intrastrand adducts [18]. The cisplatin-DNA adducts can cause cell cycle arrest, inhibition of DNA replication and transcription, and eventually apoptosis [19]. Repair inhibition of DNA has also been implicated [20] The most important repair pathways reported to be involved in cisplatin-induced DNA damage repair are nucleotide excision repair (NER) and/or homologous recombination (HR) [21,22]. An additional route for the repair of cisplatin-DNA interstrand adducts is the postreplication/translation repair pathway which helps the cell to tolerate or bypass the lesion [23]. Irradiation causes repairable (potentially lethal) and non-repairable (lethal) lesions to the DNA which are induced independently. The ultimate effect of the repairable lesions depends on competing processes of repair and misrepair. The repair of the potentially lethal damage (PLDR) is reflected by the difference in survival between immediately and delayed plated cells. Inhibition of PLDR is implicated to play a role in cisplatin-induced radiation sensitization [14]. More specifically, cisplatin-induced radiation sensitization has been shown to occur through inhibition of the nonhomologous end joining (NHEJ) pathway and recombinational repair $[18,22,24]$.

The radiation sensitization of cisplatin on the lung tumour cell line SW1573 and the cervical tumour cell line Siha is described as changes in linear and quadratic parameters of radation dose survival curves. In Figure 1 the survival curves are shown for SW1573 lung tumour cells after radiation alone and after radiation combined with cisplatin treatment $(1 \mu \mathrm{M}$ for $1 \mathrm{~h}$ ). Cisplatin was added to the cultures just before radiation. The survival curves are obtained directly (ip=immediately plated) and $24 \mathrm{~h}$ after ( $\mathrm{dp}=$ delayed plated) treatment to determine potentially lethal damage repair. A slight, but statistically significant effect of cisplatin on the radiosensitivity was only observed in delayed plated cells $(p=0.02)$. This was also described by an increase in the $\alpha$ -
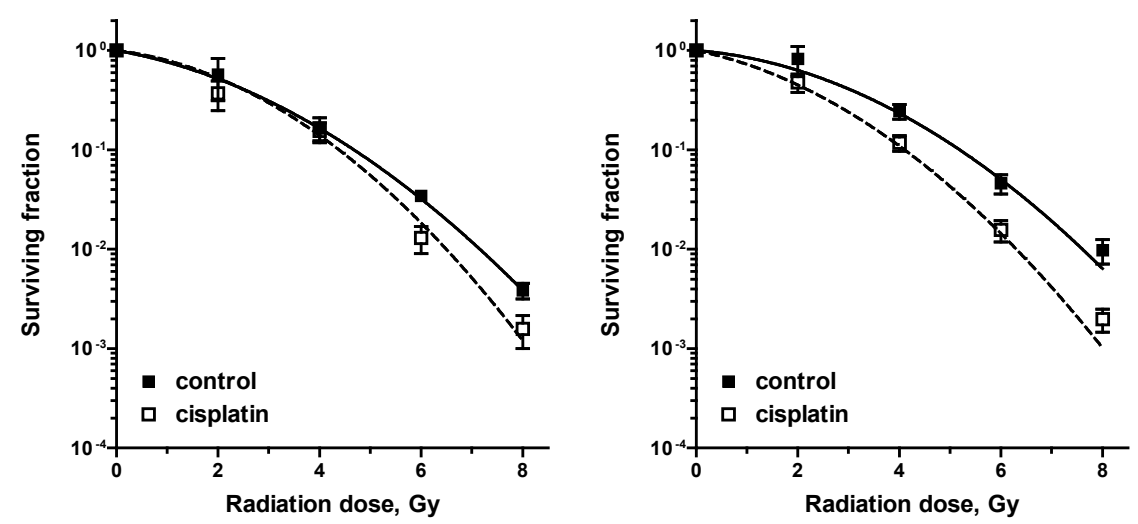

Figure 1: Radiation survival curves of confluent cultures of SW-1573 cells plated immediately after irradiation, ip (left) or $24 \mathrm{~h}$ after irradiation, dp (right) with or without $1 \mu \mathrm{M}$ cisplatin treatment for one hour. Means with standard errors of at least three experiments are shown. 
Citation: Franken NAP, Hovingh S, Rodermond H, Stalpers L, Barendsen GW, et al. (2011) Radiosensitization with Chemotherapeutic Agents and Hyperthermia: Effects on Linear-quadratic Parameters of Radiation Cell Survival Curves. J Cancer Sci Ther S5:002. doi:10.4172/19485956.S5-002

Page 3 of 10

and $\beta$-value (Table 1). Only for the delayed plated cells an increase with a factor of 2.5 for the value of $\alpha$ was obtained by cisplatin treatment. For both plating conditions an increase with a factor of 1.2 was obtained for the value of $\beta$. In the Table 1 also the effects on the linear and quadratic parameters of different plating conditions are presented as well as a $1 \mathrm{~h}$ incubation with 1 or $5 \mu \mathrm{M}$ cisplatin and a continuous incubation with cisplatin during the complete duration of the clonogenic assay. It is obvious that the cervical tumour cells Siha are more radiosensitzed with $1 \mu \mathrm{M}$ continous cisplatin incubation than the SW1573 lung tumour cells.

\section{Gemcitabine}

Gemcitabine (dFdC, Difluorodeoxycytidine) is a deoxycytidine analogue with clinical activity in non-small cell lung cancer (NSCLC) and pancreatic cancer [25-27]. It requires phosphorylation to its active metabolites, gemcitabine-diphosphate (dF-dCTP) and gemcitabine-triphosphate (dF-dCTP), with the initial phophorylation by deoxycytidine kinase (dCK) being the rate limiting step [28,29]. The dF-dCTP inhibits ribonucleotide reductase which regulates the production of deoxynucleotides necessary for DNA synthesis and repair [30]. The depletion of the deoxynucleotides leads to an increased incorporation of the dF-dCTP into DNA, blocking DNA synthesis (masked chain termination). After incorporation of the dF-dCTP into the DNA an increase in the number of DNA single-strand breaks, chromosome breaks and micronuclei has been observed [31].

Both in vitro and in vivo studies have shown that gemcitabine is a potent radiosensitizer [29,32-37]. However, in an early study in non-small cell lung cancer patients, concurrent gemcitabine and radiotherapy resulted in unacceptable pulmonary toxicity related to the large volume of radiation delivered to the lung [38]. More recent ongoing phase I trials show that concurrent gemcitabine at lower doses and radiotherapy is feasible without severe pulmonary toxicity $[26,39]$. Its unique mechanism of action, its lack of overlapping toxicity and its favourable toxicity profile define gemcitabine as an ideal candidate for combination therapy [26]. Currently many randomized studies are ongoing in which gemcitabine is combined with radiotherapy.

Gemcitabine radiosensitization is studied in a gemcitabine sensitive and resistant human lung tumour cells, SWp and SWg, resp., and in gemcitabine sensitive and resistant human ovarian tumour cells, A2780 and AG6000, resp. [40-42]. Gemcitabine was given $24 \mathrm{~h}$ before radiation treatment. The SWp is in fact similar to the SW1573 cell line which has been described above. It is called here SWp to distinguish it from SWg, the gemcitabine resistant counterpart which has been developed by van Bree et al. [40] The lung tumour cells have different sensitivities to radiation alone as compared to the ovarian cancer cells $[40,41]$.

In Table 2 the linear and quadratic parameters of the different cell lines obtained after analyses of the radiation dose survival curves for radiation alone and after combined radiation and gemcitabine treatment are summarized. SWp and SWg were almost equally sensitive to ionizing radiation alone with respect to the low dose region described by the $\alpha$-value of the linear quadratic formula (Table 2). A slight increase in survival was observed in SWg cells in the high dose region which was reflected by a slightly lower $\beta$-value of the linearquadratic formula $(0.040 \pm 0.006$ vs $0.055 \pm 0.008)$. The human ovarian carcinoma cell line A2780 and its gemcitabine-resistant variant AG6000 were equally sensitive to ionizing radiation. The surviving fractions of the different cell lines after incubation with gemcitabine alone are: SWp

\begin{tabular}{|c|c|c|c|c|c|}
\hline Cells & Treatment & $\begin{array}{l}\alpha\left(G y^{-1}\right) \\
\text { control }\end{array}$ & $\begin{array}{l}\beta\left(G y^{-2}\right) \\
\text { control }\end{array}$ & $\alpha$-enhanc factor & $\beta$-enhanc factor \\
\hline \multirow[t]{2}{*}{ SW1573 ip } & sham & $0.21 \pm 0.09$ & $0.061 \pm 0.016$ & & \\
\hline & $1 \mu \mathrm{M}$ cisplatin $(1 \mathrm{~h})$ & $0.21 \pm 0.08$ & $0.072 \pm 0.018$ & 1.0 & 1.2 \\
\hline \multirow[t]{2}{*}{ SW1573 dp } & sham & $0.10 \pm 0.09$ & $0.063 \pm 0.016$ & & \\
\hline & $1 \mu \mathrm{M}$ cisplatin (1h) & $0.25 \pm 0.09^{*}$ & $0.077 \pm 0.017$ & 2.5 & 1.2 \\
\hline \multirow[t]{3}{*}{ SW1573 ppi } & sham & $0.37 \pm 0.12$ & $0.014 \pm 0.034$ & & \\
\hline & $\begin{array}{l}1 \mu \mathrm{M} \text { cisplatin } \\
\text { (cont) }\end{array}$ & $0.41 \pm 0.08$ & $0.019 \pm 0.025$ & 1.1 & 1.4 \\
\hline & $\begin{array}{l}5 \mu \mathrm{M} \text { cisplatin } \\
\text { (cont) }\end{array}$ & $0.58 \pm 0.20^{*}$ & $0.030 \pm 0.008^{*}$ & 1.6 & 2.1 \\
\hline \multirow[t]{2}{*}{ Siha ppi } & sham & $0.41 \pm 0.04$ & $0.01 \pm 0.01$ & & \\
\hline & $1 \mu \mathrm{M}$ cisplatin (cont) & $0.81 \pm 0.12^{*}$ & $0.02 \pm 0.02$ & 2.0 & 2.0 \\
\hline
\end{tabular}

Sham is radiation only; ip=immediately plated; $d p=$ delayed plated; ppi=plated prior to irradiation. * Significant from sham $p<0.05$.

Table 1: Values of the linear-quadratic parameters $\alpha$ and $\beta$ and enhancement factors from SW1573 and Siha cells treated with ionizing radiation only and after combined radiation cisplatin ( $1 \mu \mathrm{M}$ for $1 \mathrm{~h} ; 1 \mu \mathrm{M}$ continuously; $5 \mu \mathrm{M}$ continuously) treatment.

\begin{tabular}{|c|c|c|c|c|c|}
\hline Cells & Treatment & $\begin{array}{l}\alpha\left(G y^{-1}\right) \\
\text { control }\end{array}$ & $\begin{array}{c}\beta\left(G y^{-2}\right) \\
\text { control }\end{array}$ & $\alpha$-enhanc. factor & $\beta$-enhanc. factor \\
\hline \multirow[t]{2}{*}{ SWp } & sham & $0.10 \pm 0.03$ & $0.055 \pm 0.008$ & & \\
\hline & 10nM gemcitabine & $0.30 \pm 0.06^{\star}$ & $0.053 \pm 0.007$ & 3.0 & 0.96 \\
\hline \multirow[t]{2}{*}{ SWg } & sham & $0.09 \pm 0.02$ & $0.040 \pm 0.006$ & & \\
\hline & $100 \mu \mathrm{M}$ gemcitabine & $0.09 \pm 0.03$ & $0.090 \pm 0.041^{\dagger}$ & 1.0 & 2.25 \\
\hline \multirow[t]{2}{*}{ A2780 } & sham & $0.80 \pm 0.10$ & na & & \\
\hline & 10nM gemcitabine & $1.10 \pm 0.15^{\star}$ & na & 1.4 & \\
\hline \multirow[t]{2}{*}{ AG6000 } & sham & $0.83 \pm 0.13$ & na & & \\
\hline & $50 \mu \mathrm{M}$ gemcitabine & $1.11 \pm 0.20^{\dagger}$ & na & 1.3 & \\
\hline
\end{tabular}

Significant difference with ${ }^{*} P<0.01,{ }^{+} P<0.05$, na is not applicable

Table 2: Values of the linear-quadratic parameters $\alpha$ and $\beta$ and enhancement factors from cells treated with ionizing radiation only and gemcitabine-sensitized radiation dose survival curves of gemcitabine-sensitive (SWp and A2780) and gemcitabine-resistant (SWg and AG6000) cells. 
Citation: Franken NAP, Hovingh S, Rodermond H, Stalpers L, Barendsen GW, et al. (2011) Radiosensitization with Chemotherapeutic Agents and Hyperthermia: Effects on Linear-quadratic Parameters of Radiation Cell Survival Curves. J Cancer Sci Ther S5:002. doi:10.4172/19485956.S5-002

$10 \mathrm{nM}: 0.52 \pm 0.06 ;$ SWg $10 \mu \mathrm{M}: 0.95 \pm 0.03,100 \mu \mathrm{M}: 0.24 \pm 0.11 ; \mathrm{A} 2780$ $2 \mathrm{nM}: 0.82 \pm 0.08,10 \mathrm{nM}: 0.21 \pm 0.08$; AG6000 $20 \mu \mathrm{M}: 0.62 \pm 0.07,50$ $\mu \mathrm{M}: 0.22 \pm 0.04$

As can be observed in Figure 2 and Table 2 radiosensitization is observed with gemcitabine-sensitive as well as in gemcitabine resistant cells. For the resistant cells much higher gemcitabine doses are needed for the radiation sensitization to result in similar cytotoxicity. Both gemcitabine-sensitive cell lines SWp and A2780 are sensitized by incubation with $10 \mathrm{nM}$ of gemcitabine for $24 \mathrm{~h}$ before irradiation while the SWg and AG6000 are not sensitized with this dose of gemcitabine. The sensitization is described by an increase in the $\alpha$-values with factors of 3 and 1.4 respectively, whereas the $\beta$-values are not significantly altered. Higher concentrations of Gemcitabine (50 and $100 \mathrm{nM}$ resp.) are required to sensitize gemcitabine-resistant AG6000 and SWg cells to irradiation. For the SWg cells, the radiosensitization was reflected by an increase by a factor of 2.25 in the value of $\beta$, whereas in the AG6000 only the $\alpha$-value was increased by factor of 1.3 .

\section{Iodo-deoxyUridine (IdUrd)}

Incorporation of halogenated pyrimidines (HPs), chloro-, bromoand iodo-deoxyuridine (CldUrd, BrdUrd, IdUrd) into DNA is known to sensitise cells to ionizing radiation [43-51]. Halogenated pyrimidines are incorporated into the DNA replacing the thymidine. The induced radiosensitisation increases with the degree of thymidine-replacement. The mechanism of radiation sensitisation by the HPs has been suggested to be either an increase in the amount of DNA damage induced by radiation, an influence on repair of sublethal damage (SLD), and/or an enhanced expression of potentially lethal damage (PLD) $[43,52]$. Since different processes are involved in these phenomena several mechanisms might contribute to the radiosensitisation.

HPs have been suggested to provide an advantage in radiotherapy as radiosensitisers of cells in rapidly growing tumours, in particular in clinical conditions in which critical normal tissues show limited proliferation and as a consequence take up less HP. Labelling depends on the growth fraction, cell loss, cell cycle time and potential doubling time. Of special importance for sensitisation is the rate at which noncycling cells are recruited into the proliferative compartment during exposure to HPs and a course of radiotherapy. However, even in rapidly growing tumours, cells may, after proliferative cycles, move into a non-proliferative stage. This might compromise the degree of radiation sensitisation if resting cells are less affected by HPs, or are better able to cope with additional damage by repair of PLD.

Here the results of radiosensitization after incubation with $4 \mu \mathrm{M}$ IdUrd for $72 \mathrm{~h}$ are presented. IdUrd-induced radio sensitisation was obtained in all studied cell lines, SW-1573 (human lung cancer), RUCII (Rat urether carcinoma), R1 (Rat rhabdomyosarcoma) and V79 (hamster fibroblast cells), in exponentially growing and in plateauphase cells. Survival curves of SW-1573 cells are presented in Figure 3. Values of $\alpha$ and $\beta$ derived by linear-quadratic analyses of survival curves of exponentially growing cells and plateau-phase cells are presented in Table 3. The plating conditions of the V79 cells, i.e. exponentially growing cells plating before or after irradiation (ppi or pai resp.),
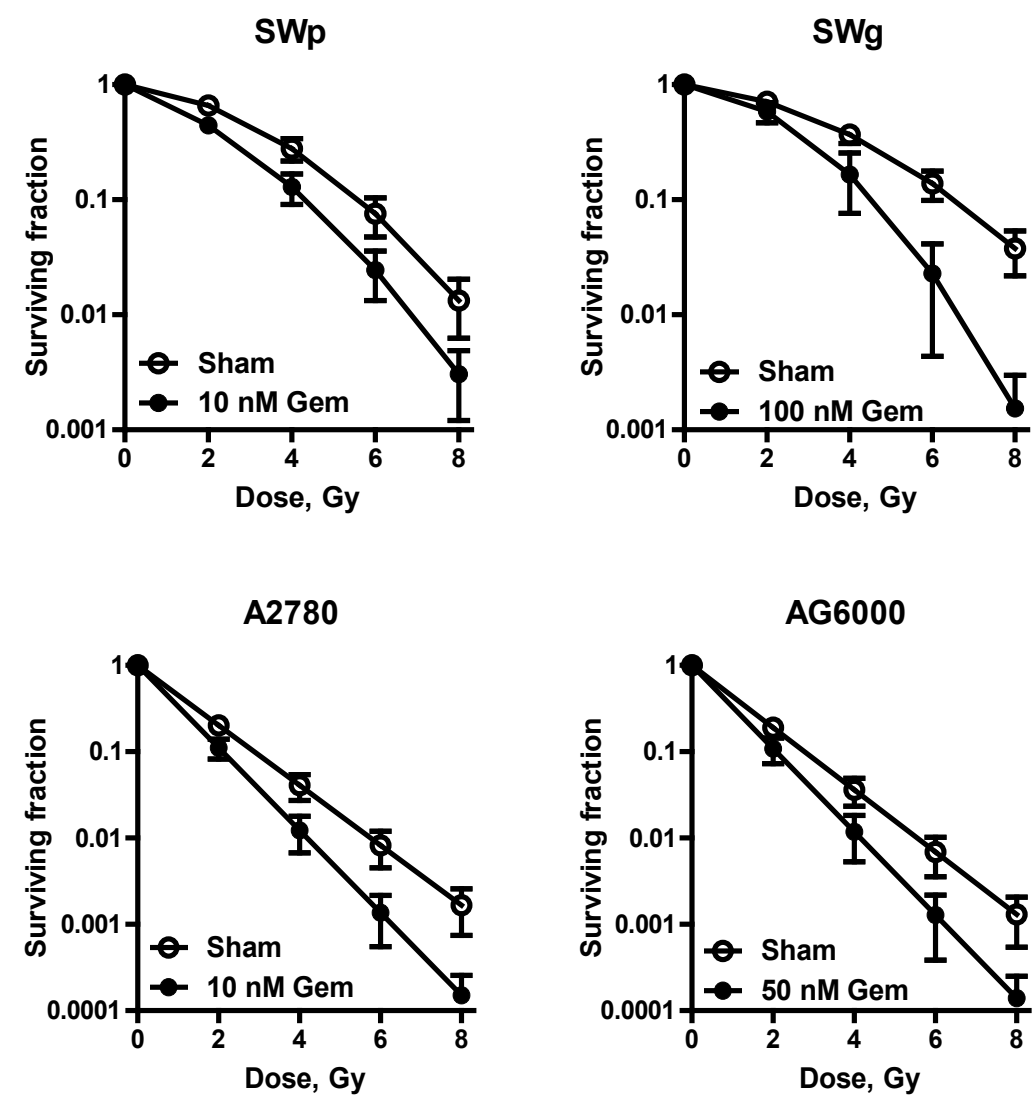

Figure 2: Radiation sensitization after $24 \mathrm{~h}$ incubation with different concentrations of gemcitabine in gemcitabine sensitive SWp and resistant SWg lung tumour cells and in gemcitabine sensitive A2780 and resistant AG6000 ovary cancer cells. Surviving fractions are corrected for gemcitabine toxicity alone (for values see text). Cells are plated immediately after irradiation. Means with SEM of at least three separate experiments are shown. 
Citation: Franken NAP, Hovingh S, Rodermond H, Stalpers L, Barendsen GW, et al. (2011) Radiosensitization with Chemotherapeutic Agents and Hyperthermia: Effects on Linear-quadratic Parameters of Radiation Cell Survival Curves. J Cancer Sci Ther S5:002. doi:10.4172/19485956.S5-002

Page 5 of 10
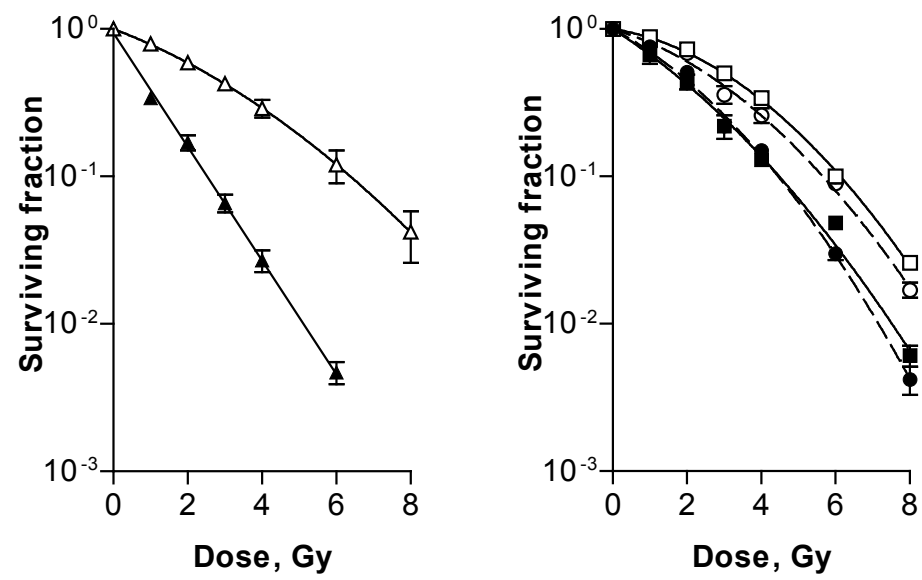

Figure 3: Radiation dose-survival curves of SW-1573 human lung cancer cells exponentially growing (left) without IdUrd (open triangles) and after incubation with 4 M IdUrd (closed triangles) and in plateau-phase (right) plated immediately after irradiation (dashed lines) and plated $24 \mathrm{~h}$ after irradiation (solid lines) without IdUrd (open symbols) and after incubation with $4 \mu \mathrm{M}$ IdUrd (closed symbols). Each point represents the mean value of 3 different experiments \pm sem.

\begin{tabular}{|c|c|c|c|c|c|c|}
\hline Cell line & $\begin{array}{l}\alpha\left(G y^{-1}\right) \\
\text { control }\end{array}$ & $\begin{array}{l}\beta\left(G^{-2}\right) \\
\text { control }\end{array}$ & $\begin{array}{c}\alpha\left(G^{-1}\right) \\
\text { IdUrd-sens }\end{array}$ & $\begin{array}{c}\beta\left(G y^{-2}\right) \\
\text { IdUrd-sens }\end{array}$ & $\begin{array}{l}\alpha \text {-enhanc } \\
\text { factor }\end{array}$ & $\begin{array}{c}\beta \text {-enhanc } \\
\text { factor }\end{array}$ \\
\hline $\begin{array}{l}\text { SW } 1573 \text { cells } \\
\text { Exp growing ip }\end{array}$ & $0.22 \pm 0.01$ & $0.022 \pm 0.001$ & $0.83 \pm 0.06$ & na & 3.8 & \\
\hline $\begin{array}{l}\text { SW } 1573 \text { cells } \\
\text { Plateau phase ip }\end{array}$ & $0.17 \pm 0.03$ & $0.042 \pm 0.004$ & $0.31 \pm 0.03$ & $0.047 \pm 0.005$ & 1.8 & 1.1 \\
\hline $\begin{array}{l}\text { SW } 1573 \text { cells } \\
\text { Plateau phase dp }\end{array}$ & $0.09 \pm 0.02$ & $0.046 \pm 0.002$ & $0.37 \pm 0.04$ & 0.0330 .006 & 4.1 & 0.7 \\
\hline $\begin{array}{l}\text { RUCIl cells } \\
\text { Exp growing ppi }\end{array}$ & $0.008 \pm 0.007$ & $0.025 \pm 0.001$ & $0.06 \pm 0.02$ & $0.026 \pm 0.001$ & 7.5 & 1.04 \\
\hline $\begin{array}{l}\text { R1 cells } \\
\text { Exp growing ppi }\end{array}$ & $0.23 \pm 0.01$ & $0.068 \quad 0.003$ & $0.44 \pm 0.05$ & $0.075 \pm 0.016$ & 1.9 & 1.1 \\
\hline $\begin{array}{l}\text { V79 cells } \\
\text { Exp growing ip }\end{array}$ & $0.18 \pm 0.02$ & $0.017 \pm 0.003$ & $0.38 \pm 0.04$ & $0.023 \quad 0.007$ & 2.1 & 1.4 \\
\hline $\begin{array}{l}\text { V79 cells } \\
\text { Exp growing ppi }\end{array}$ & $0.15 \pm 0.02$ & $0.013 \pm 0.003$ & $0.29 \pm 0.03$ & $0.016 \quad 0.004$ & 1.9 & 1.2 \\
\hline $\begin{array}{l}\text { V } 79 \text { cells } \\
\text { Plateau phase ip }\end{array}$ & $0.09 \pm 0.03$ & $0.026 \pm 0.004$ & $0.17 \pm 0.02$ & 0.0620 .005 & 1.9 & 2.4 \\
\hline $\begin{array}{l}\text { V } 79 \text { cells } \\
\text { Plateau phase dp }\end{array}$ & $0.07 \pm 0.02$ & $0.020 \pm 0.002$ & $0.30 \pm 0.03$ & 0.0240 .004 & 4.3 & 1.2 \\
\hline
\end{tabular}

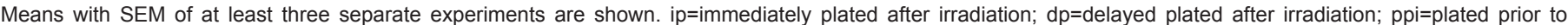
irradiation; na=not applicable.

Table 3: Values of the linear-quadratic parameters $\alpha$ and $\beta$ and enhancement factors of several cell lines treated with ionizing radiation only and after sensitization with iododeoxyuridine (incubation with $4 \mu \mathrm{M}$ IdUrd for $72 \mathrm{~h}$ ).

and plateau phase cells plated immediately or 6-24 h delayed after irradiation (ip or dp resp.) had no influence on the factor of increase of the $\alpha$-value. It is shown that the value of the linear parameter, $\alpha$ can be enhanced by a factor of 1.9 to 7.5 and that in general low values of $\alpha$ are enhanced more than higher values of $\alpha$. The value of $\beta$ is less enhanced and the enhancement factor ranges from 0.7 to 2.4.

The direct comparison between immediate and delayed plating of plateau-phase cells and between plateau phase and exponentially growing cells shows significant quantitative differences. The data on the linear and quadratic parameters described here provide various new insights in the interpretation of radiosensitisation of delay plated plateau-phase cells. It is demonstrated that in delay plated HPsensitized plateau phase cells PLD is not abolished.

\section{Hyperthermia}

Hyperthermia refers to heat treatments if cells or malignancies in which the temperature is elevated in the range of $39^{\circ} \mathrm{C}$ to $45^{\circ} \mathrm{C}$. It is used in combination with chemo- and/or radiotherapy since it is has been shown to enhance the anti-cancer effects of both therapies [53-57]. Many in vitro studies on the combination of hyperthermia and radiation have shown a synergistic interaction between the two modalities, especially at higher temperatures (above $42^{\circ} \mathrm{C}$ ) [58-60]. This interaction is believed to result from inhibition of repair of radiationinduced DNA damage by hyperthermia [61,62]. The sequence of combined radiation and hyperthermia treatment is important. Optimal sensitization is obtained when radiation and hyperthermia are applied simultaneously or with a short interval [63]. In the clinic this is not always possible. In our experiments hyperthermia was applied immediately after radiation treatment.

Despite the clinical goal to reach (cytotoxic) temperatures as high as $43^{\circ} \mathrm{C}$, tumour temperature distributions are in practice heterogeneous. In large areas of the tumour temperatures are often lower than $43^{\circ} \mathrm{C}$. 
Citation: Franken NAP, Hovingh S, Rodermond H, Stalpers L, Barendsen GW, et al. (2011) Radiosensitization with Chemotherapeutic Agents and Hyperthermia: Effects on Linear-quadratic Parameters of Radiation Cell Survival Curves. J Cancer Sci Ther S5:002. doi:10.4172/19485956.S5-002

Page 6 of 10

Nonetheless, good results have been obtained in locally advanced cervical cancers with tumour temperatures below $43^{\circ} \mathrm{C}$ [54]. Mild temperatures have more subtle effects than high temperatures, such as tumour-reoxygenation [64-67]. Recently it has been shown that hyperthermia $\left(42^{\circ} \mathrm{C}\right.$ for $\left.1 \mathrm{~h}\right)$ transiently breaks down the BRCA2 protein [68]. In this paragraph the effects of hyperthermia treatment for $1 \mathrm{~h}$ at 41 or $43^{\circ} \mathrm{C}$ on the linear quadratic parameters are summarized. Several different cell types have been studied.

Effect of hyperthermia treatment on radiosensitivity of RKO cells: The RKO cells, derived from human colon cancer, are relatively sensitive to hyperthermia treatment. Hyperthermia treatment for $1 \mathrm{~h}$ at $43^{\circ} \mathrm{C}$ decreases the relative survival to less than 0.01 and combination with radiation doses in excess of $5 \mathrm{~Gy}$ always resulted in a situation in which no colony formation was observed. Treatment of cells with $41^{\circ} \mathrm{C}$ hyperthermia (1h) alone had little effect and resulted in a surviving fraction of $0.8 \pm 0.4$ in immediately plated (ip) cells and of 0.9 \pm 0.1 in delayed plated (dp) cells. When cells were treated at $41^{\circ} \mathrm{C}$ for $1 \mathrm{~h}$ immediately prior to irradiation, a significant $(p<0.001)$ enhancement of cellular radiosensitivity was observed both in ip (Figure 4) and dp (Figure 4) cells.

The effects of hyperthermia on the LQ parameters are summarized in Table 4 . The value of the linear parameter $\alpha$ increased by a factor 1.71.8 while the value of the $\beta$ parameter even increased with a factor as high as 2.5-7.0. One must bear in mind that the quadratic component in this cell line is very small and small changes can have large on the numerical values of $\beta$.

Effect of hyperthermia treatment on radiosensitivity of SW1573 cells: SW-1573 cells are derived from a human lung tumour and are much less sensitive to hyperthermia treatment than RKO cells. Studies were performed to evaluate whether pretreatment with hyperthermia at $41^{\circ} \mathrm{C}$ or at $43^{\circ} \mathrm{C}$ in SW- 1573 cells was able to enhance the radiosensitivity of these cells. Hyperthermia treatment at $41^{\circ} \mathrm{C}$ for $1 \mathrm{~h}$ without radiation did not result in a decrease of the surviving fraction for ip and dp cells as compared to radiation alone. One hour hyperthermia treatment at $43{ }^{\circ} \mathrm{C}$ decreased survival to $0.5 \pm 0.1$ for ip and to $0.4 \pm 0.2$ for dp cells. Pre-treatment of cells at $41^{\circ} \mathrm{C}$ for $1 \mathrm{~h}$ did not alter cellular radiosensitivity of both ip and dp cells (Figure 5). However, $1 \mathrm{~h}$ treatment at $43^{\circ} \mathrm{C}$ resulted in a significant $(\mathrm{p}<0.001)$ radiation enhancement both in ip and dp cells (Figure 5). In Table 4 the values of the linear-quadratic parameters for radiation alone and for combined treatments are given. Hyperthermia treatment for $1 \mathrm{~h}$ at $41^{\circ} \mathrm{C}$ did result in an increase of the value of $\beta$ by a factor 1.3-1.8 while the value of $\alpha$ even decreased. Hyperthermia treatment for $1 \mathrm{~h}$ at $43^{\circ} \mathrm{C}$ result in an increase of the value of $\alpha$ by a factor 2.3-4.4 while the value $\beta$ increased with a factor 1.8-2.0.

\section{Discussion and Conclusion}

In most cases an increase of the $\alpha$-component was observed which
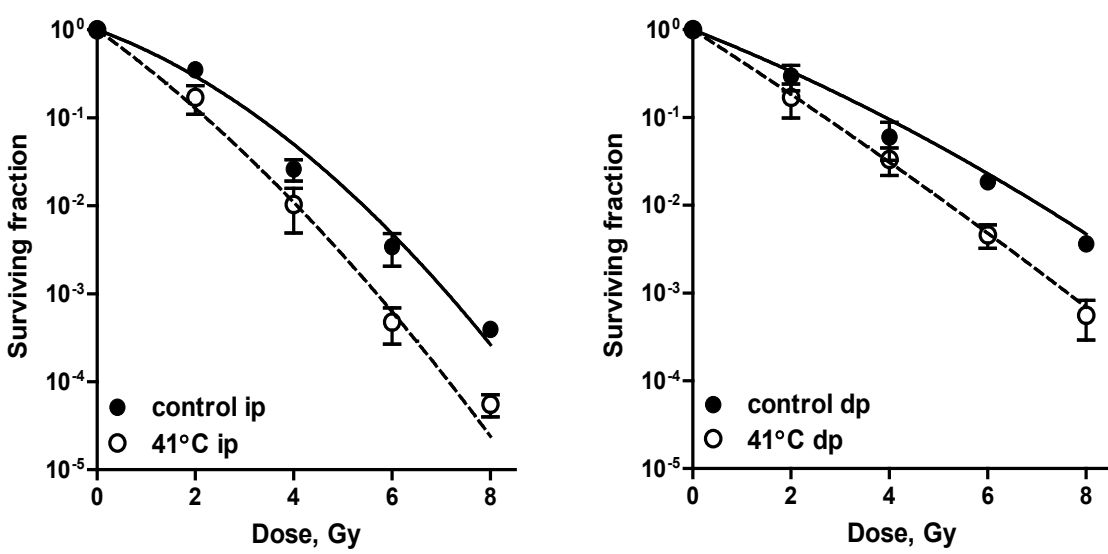

Figure 4: Radiation survival curves of confluent cultures of RKO cells (human colon cancer cells) plated immediately after irradiation, ip (left) or 24h after irradiation, $\mathrm{dp}$ (right) with or without hyperthermia pre-treatment at $41^{\circ} \mathrm{C}$ for $1 \mathrm{~h}$. Means with standard errors of at least three experiments are shown.

\begin{tabular}{|c|c|c|c|c|c|}
\hline Cells & Treatment & $\begin{array}{l}\alpha\left(G^{-1}\right) \\
\text { control }\end{array}$ & $\begin{array}{l}\beta\left(\mathrm{Gy}^{-2}\right) \\
\text { control }\end{array}$ & a-enhanc factor & $\beta$-enhanc factor \\
\hline \multirow[t]{2}{*}{ RKO ip } & sham & $0.55 \pm 0.09$ & $0.02 \pm 0.01$ & & \\
\hline & HT $411 \mathrm{~h}$ & $0.93 \pm 0.09$ & $0.05 \pm 0.02$ & 1.7 & 2.5 \\
\hline \multirow[t]{2}{*}{ RKO dp } & sham & $0.47 \pm 0.09$ & $0.01 \pm 0.01$ & & \\
\hline & HT 41 1h & $0.83 \pm 0.08$ & $0.07 \pm 0.02$ & 1.8 & 7.0 \\
\hline \multirow[t]{3}{*}{ SW1573 ip } & sham & $0.21 \pm 0.02$ & $0.06 \pm 0.02$ & & \\
\hline & HT 41 1h & $0.06 \pm 0.02$ & $0.11 \pm 0.03$ & 0.3 & 1.8 \\
\hline & HT $431 \mathrm{~h}$ & $0.49 \pm 0.04$ & $0.12 \pm 0.03$ & 2.3 & 2.0 \\
\hline \multirow[t]{3}{*}{ SW1573 dp } & sham & $0.09 \pm 0.02$ & $0.06 \pm 0.02$ & & \\
\hline & HT $411 \mathrm{~h}$ & $0.05 \pm 0.02$ & $0.08 \pm 0.02$ & 0.6 & 1.3 \\
\hline & HT $431 \mathrm{~h}$ & $0.40 \pm 0.04$ & $0.11 \pm 0.03$ & 4.4 & 1.8 \\
\hline
\end{tabular}

Sham=control is radiation only; ip=immediately plated; $\mathrm{dp}=$ delayed plated.

Table 4: Values of the linear-quadratic parameters $\alpha$ and $\beta$ and enhancement factors from cells treated with ionizing radiation only and after combined radiation and hyperthermia treatment. 
Citation: Franken NAP, Hovingh S, Rodermond H, Stalpers L, Barendsen GW, et al. (2011) Radiosensitization with Chemotherapeutic Agents and Hyperthermia: Effects on Linear-quadratic Parameters of Radiation Cell Survival Curves. J Cancer Sci Ther S5:002. doi:10.4172/19485956.S5-002

Page 7 of 10

corresponds to an enhanced (potentially) direct lethal damage (PLD) at low doses. The $\beta$-component, which is assumed to depend on the interaction of sublethal lesions (SLD), was rarely affected by the studied radiosensitization agents. Moreover, it appeared that more radioresistant cell lines were more sensitised than the radiosensitive lines. Furthermore it can be concluded that radiosensitization is also dependent on cell cycle stage like plateau or exponentially growing phase or post treatment plating conditions [69].

It is shown that cisplatin causes radiosensitization as measured by clonogenic survival, but only after allowing a potentially lethal damage repair (PLDR) time of 24 hours. These results are in agreement with those of Wilkins et al. [70] who investigated the effect of cisplatin and radiation on PLDR in confluent cultures of two different brain tumor cell lines. Wilkins et al. [71] also observed no radiosensitization by cisplatin in immediately plated cells whereas a cisplatin-induced radiosensitization was seen in cells plated eight hours after irradiation. Their results indicate that the radiosensitizing effect of cisplatin occurs through the inhibition of post-irradiation recovery. The strongest inhibition of PLDR was achieved when cisplatin was administered shortly before or after irradiation [70]. In our experiments, cells were irradiated while cisplatin was present in the medium.

Results from studies using exponentially growing cell cultures vary from a cisplatin-induced radiosensitization [11-13,71] to only an additive effect $[9,11,72-74]$. The effect of cisplatin treatment on radiosensitivity may depend on the cell type used. Loprevite et al. [11] observed synergism in a squamous lung carcinoma cell line when exposed to cisplatin, whereas an adenocarcinoma of the lung was not sensitized by cisplatin. Even cell lines derived from a single biopsy can differ in the response to cisplatin and radiation combination therapy [74].

Although dependence on cell cycle phase [75,76], cisplatin incubation time and the sequence of treatment modalities have been implicated $[9,75,76]$, there is currently no consensus to account for the varying response of cells to cisplatin and radiation.

The mechanism of cisplatin induced radiosensitization might be due to the inhibition of the DNA repair, NHEJ and HR, pathways $[19,24]$. The $\mathrm{Ku}$ protein complex, which plays an important role in NHEJ, was demonstrated to show a reduced ability to translocate on DNA containing cisplatin-DNA adducts compared with undamaged DNA.
This resulted in a decreased interaction between $\mathrm{Ku}$ and DNA-PK ${ }_{\mathrm{cs}}[77]$ However, the biochemical processes that cisplatin undergoes in the cell are complex and the intracellular fate of cisplatin may be linked to copper transport [78]. Therefore, other processes such as the formation of peroxy complexes inside the cell might be involved in cisplatininduced radiosensitization [14,79]. Bergs et al. [14] demonstrated an increase in the induction of apoptosis after combined treatment as compared to radiation or cisplatin alone at $24 \mathrm{~h}$ after treatment. This was confirmed in several other studies $[80,81]$. These apoptotic effects observed by Bergs et al. [14] correlated with clonogenic survival. Fujita et al. [82] also observed an inhibitory effect of the combination of cisplatin and radiation on the survival of lung tumor cells and ascribed this effect on the induction of tumor cell apoptosis.

In conclusion, a radiosensitizing effect of cisplatin on cell survival is observed in confluent cultures when cells were replated after a 24 hour incubation period during which PLD repair could take place. In contrast, cisplatin did not induce a significant radiosensitization after immediate plating.

Several studies have shown that gemcitabine is a potent sensitizer of ionizing radiation $[29,34,83]$. Among other proposed mechanisms of action, the effect of gemcitabine on cell cycle distributions may be the most important $[35,36]$. In our studies, both gemcitabine-sensitive cell lines SWp and A2780 could be sensitized to irradiation when cytotoxic gemcitabine-treatments were given. The radiosensitization was accompanied by a clear arrest of cells in early $S$ phase which has been argued to be vital for gemcitabine-induced radiosensitization [33]. Both cell lines showed an increase in $\alpha$-value indicating the efficacy of gemcitabine-induced radiosensitization in the clinically relevant dose range. Although the gemcitabine resistant cells still could be sensitized only much higher gemcitabine doses were necessary to reach an effect. In the resistant ovarian carcinoma cell line AG6000 this was demonstrated by an increase in the value of $\alpha$. In contrast with this change, in the gemcitabine resistant lung tumour cell line an increase in the $\beta$-value was obtained, the $\alpha$-value was not affected. In both gemcitabine-resistant cell lines the sensitivity to ionizing radiation alone was not altered. It is reported that gemcitabine resistant tumours are cross-resistant to related drugs like Ara-c [84,85]. In both gemcitabine-resistant cell line, AG6000 and SWg, this was indeed the case [40]. Moreover, the AG6000 cells were also more resistant to cisplatin and taxoids (41). However, no altered sensitivity was found
SW-1573

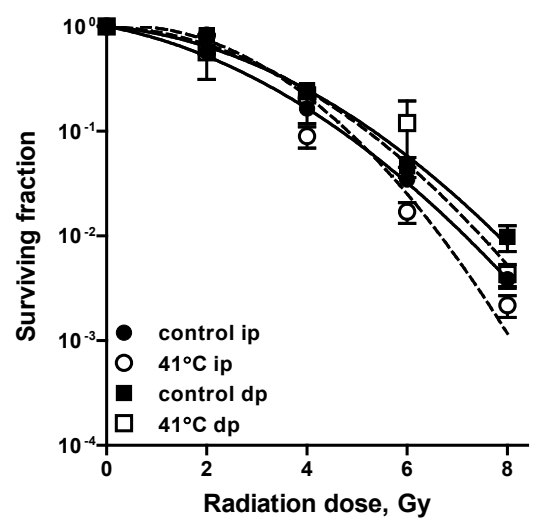

SW-1573

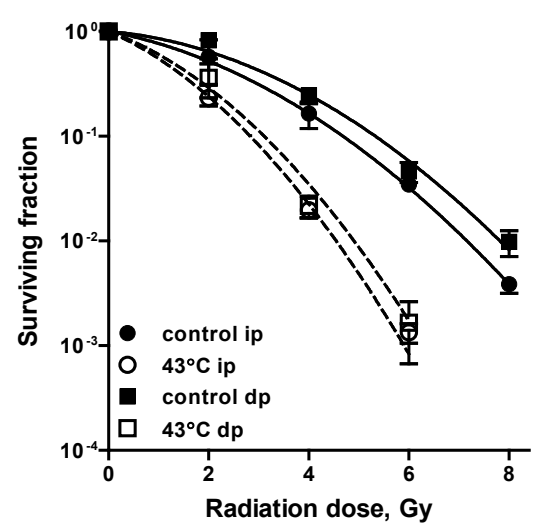

Figure 5: Radiation survival curves of confluent cultures of SW-1573 cells (human lung tumour cells) plated immediately after irradiation (ip) or $24 \mathrm{~h}$ after irradiation ( $\mathrm{dp}$ ) with or without hyperthermia pre-treatment at $41^{\circ} \mathrm{C}$ (left) or at $43^{\circ} \mathrm{C}$ (right) for $1 \mathrm{~h}$. Means with standard errors of at least three experiments are shown. 
Citation: Franken NAP, Hovingh S, Rodermond H, Stalpers L, Barendsen GW, et al. (2011) Radiosensitization with Chemotherapeutic Agents and Hyperthermia: Effects on Linear-quadratic Parameters of Radiation Cell Survival Curves. J Cancer Sci Ther S5:002. doi:10.4172/19485956.S5-002

in SWg cells for cDDP, paclitaxel, MTX and 5 FU, while AG6000 cells were 2.5-fold more sensitive to MTX [41]. These findings indicate that patients previously treated with gemcitabine may receive additional radiotherapy with or without cDDP or paclitaxel.

The HP-induced-radiosensitisation is mainly due to an increase in the linear parameter $\alpha$. The quadratic parameter, $\beta$, is only rarely influenced. Different mechanisms involved in the radiosensitisation induced by halogenated pyrimidines have been described [43]. Wang et al. [86] suggested that in exponentially growing cells increased DNA damage production was the major component of radiosensitisation while in plateau-phase cells radiosensitisation occurred through inhibited repair and/or enhanced fixation of potentially lethal damage. The increase of the a values for exponentially growing cells as found in our study, indicates an increase in the number of directly lethal events due to the HPs. This is in agreement with observations of Webb et al. [52] and Jones et al. [87] which suggest that an important mechanism of radiosensitisation involves an increase of effective DNA double strand breaks. Miller et al. [50,51] have suggested that radiationinduced damage in cells which have HPs incorporated into the DNA after low-LET irradiation resembles the damage produced by high-LET radiation. In plateau-phase cells plated immediately after irradiation the increase of a might be due to the same mechanism as involved in exponentially growing cells. In these cells also an increase of $\beta$ was observed indicating that accumulation of sublethal lesions contributed significantly [2]. Due to the immediate plating after irradiation this sublethal damage might be fixated. Greatest increases in a were found in delayed plated plateau-phase cells. This radiosensitisation can be interpreted as an enhanced fixation of potentially lethal damage due to immediate DNA damage and/or to damaged DNA repair function in these cells expressed during the interval before delayed plating. The value of $\beta$ in these cells returned to values as found in cells not containing HPs. This demonstrates that sublethal damage has been repaired in HP-containing plateau-phase cells.

Hyperthermia is an excellent radiosensitizer which can already be effective at mild temperatures. One hour hyperthermia treatment at $41^{\circ} \mathrm{C}$ without radiation had only a small cytotoxic effect in both the heat sensitive and the heat resistant cell line. This is in agreement with the general idea of cell kill induction at temperatures $\geq 42^{\circ} \mathrm{C}$ for $1 \mathrm{~h}$ or more Dewhirst, 2005 [64]). Hyperthermia treatment at $43^{\circ} \mathrm{C}$ for $1 \mathrm{~h}$ did not have a large cytotoxic effect in heat resistant SW-1573 cells. Radiosensitization by $41^{\circ} \mathrm{C}$ temperature hyperthermia was observed in $\mathrm{RKO}$, but not in SW-1573 cells. The ability of mild temperatures (in the range of $40-42^{\circ} \mathrm{C}$ ) hyperthermia to increase radiosensitivity of human tumor cells has been shown to be cell line dependent $[66,67,88-93]$. In a study by Xu et al. [94] $41.1^{\circ} \mathrm{C}$ pre-treatment of cells for $1 \mathrm{~h}$ did not induce radiosensitization whereas treatment for $2 \mathrm{~h}$ or more resulted in radiosensitization, in the hyperthermia resistant, but not in the hyperthermia sensitive cell line [94]. However, simultaneous treatment of the sensitive cell line with $1 \mathrm{~h} 41.1^{\circ} \mathrm{C}$ hyperthermia and radiation did increase cellular radiosensitivity [95]. An important mechanism of mild hyperthermia induced radiosensitization in vivo is the reoxygenation of tumors by an increase in blood flow [96-98]. Recently it was demonstrated that the BRCA-2 protein is transiently inhibited by mild hyperthermia $[68,99]$. Also translocation of the Mre11 DSB repair protein from the nucleus to the cytoplasm has been implicated $[95,100]$. However, disappearance of Mre11 protein foci at the sites of irradiation induced DNA double strand breaks by $41^{\circ} \mathrm{C}$ pre-incubation of cells was not observed [66-68]. A role for mitotic catastrophe occurring as a result of $\mathrm{G} 2 / \mathrm{M}$ checkpoint abrogation has also been suggested [101]. It has been shown that radiosensitization by $41-43^{\circ} \mathrm{C}$ hyperthermia correlates with an increased number of chromosomal fragments, but not of color junctions, at $24 \mathrm{~h}$ after treatment compared to radiation alone [67].

\section{Acknowledgements}

The authors are thankful for financial support from several foundations. The Maurits and Anna de Kock and the Nijbakker Morra foundations are acknowledged for sponsoring laboratory equipment. The Dutch Cancer Foundation (grant \# UVA 2006-3484, \# UVA 2008-4019) and the Stichting Vanderes are acknowledged for financing personnel support.

\section{References}

1. Franken NAP, Hovingh S, Oei A, Cobussen P, Bergs JWJ, et al. (2012) Radiosensitization with hyperthermia and chemotherapeutic agents: Effects on linear-quadratic parameters of radiation cell survival curves (Review). In Ionizing Radiation/Book 1, Editor: Mitsuru Nenoi; Intech publisher.

2. Barendsen GW (1990) Mechanisms of cell reproductive death and shapes of radiation dose-survival curves of mammalian cells. Int J Radiat Biol 57: 885896

3. Barendsen GW (1994) The relationship between RBE and LET for different types of lethal damage in mammalian cells: biophysical and molecular mechanisms. Radiat Res 139: 257-270.

4. Barendsen GW (1997) Parameters of linear-quadratic radiation dose-effect relationships: dependence on LET and mechanisms of reproductive cell death Int J Radiat Biol 71: 649-655.

5. Barendsen GW, Van Bree C, Franken NA (2001) Importance of cell proliferative state and potentially lethal damage repair on radiation effectiveness: implications for combined tumor treatments (review). Int J Oncol 19: 247-256.

6. Franken NAP, Rodermond HM, Stap J, Haveman J, Van Bree C (2006) Clonogenic assay of cells in vitro. Nature Prot 1: 2315-2319.

7. Joiner M, Van der Kogel A (2006) Basic clinical radiobiology (4th Edn), Hodde Arnold.

8. Barendsen GW (1982) Dose fractionation, dose rate and iso-effect relationships for normal tissue responses. Int J Radiat Oncol Biol Phys 8: 1981-1997.

9. Gorodetsky R, Levy-Agababa F, Mou X, Vexler AM (1998) Combination of cisplatin and radiation in cell culture: effect of duration of exposure to drug and timing of irradiation. Int J Cancer 75: 635-642.

10. Dueñas-Gonzalez A, Cetina L, Mariscal I, de la Garza J (2003) Modern management of locally advanced cervical carcinoma. Cancer Treat Rev 29 389-399.

11. Loprevite M, Favoni RE, de Cupis A, Pirani P, Pietra G, et al. (2001) Interaction between novel anticancer agents and radiation in non-small cell lung cancer cell lines. Lung Cancer 33: 27-39.

12. Begg AC, Van der Kolk PJ, Dewit L, Bartelink H (1986) Radiosensitization by cisplatin of RIF1 tumour cells in vitro. Int J Radiat Biol Relat Stud Phys Chem Med 50: 871-884.

13. Nakamoto S, Mitsuhashi N, Takahashi T, Sakurai H, Niibe H (1996) An interaction of cisplatin and radiation in two rat yolk sac tumour cell lines with different radiosensitivities in vitro. Int J Radiat Biol 70: 747-753.

14. Bergs JW, Franken NA, ten Cate R, van Bree C, Haveman J (2006) Effects of cisplatin and gamma-irradiation on cell survival, the induction of chromosomal aberrations and apoptosis in SW-1573 cells. Mutat Res 594: 148-154.

15. Bergs JWJ (2007) Hyperthermia, cisplatin and radiation trimodality treatment: In vitro studies on interaction mechanisms. PhD. Thesis, University of Amsterdam.

16. Fehlauer F, Barten-Van Rijbroek AD, Stalpers LJ, Leenstra S, Lindeman J, et al. (2000) Additive cytotoxic effect of cisplatin and X-irradiation on human glioma cell cultures derived from biopsy-tissue. J Cancer Res Clin Oncol 126 711-716.

17. Rabik CA, Dolan ME (2007) Molecular mechanisms of resistance and toxicity associated with platinating agents. Cancer Treat Rev 33: 9-23.

18. Crul M, van Waardenburg RC, Beijnen JH, Schellens JH (2002) DNA-based drug interactions of cisplatin. Cancer Treat Rev 28: 291-303.

19. Myint WK, Ng C, Raaphorst GP (2002) Examining the non-homologous repai process following cisplatin and radiation treatments. Int J Radiat Biol 78: 417-424. 
Citation: Franken NAP, Hovingh S, Rodermond H, Stalpers L, Barendsen GW, et al. (2011) Radiosensitization with Chemotherapeutic Agents and Hyperthermia: Effects on Linear-quadratic Parameters of Radiation Cell Survival Curves. J Cancer Sci Ther S5:002. doi:10.4172/19485956.S5-002

20. Lawrence TS, Blackstock AW, McGinn C (2003) The mechanism of action of radiosensitization of conventional chemotherapeutic agents. Semin Radia Oncol 13: 13-21.

21. Haveman J, Castro Kreder N, Rodermond HM, Van Bree C, Franken NA, et al. (2004) Cellular response of X-ray sensitive hamster mutant cell lines to gemcitabine, cisplatin and 5-fluorouracil. Oncol Rep 12: 187-192.

22. De Silva, IU, McHugh PJ, Clingen PH, Hartley JA (2002) Defects in interstrand cross-link uncoupling do not account for the extreme sensitivity of ERCC1 and XPF cells to cisplatin. Nucleic Acids Res 30: 3848-3856.

23. Dronkert MLG, Kanaar R (2001) Repair of DNA interstrand cross-links. Muta Res 486: 217-247.

24. Dolling JA, Boreham DR, Brown DL, Raaphorst GP, Mitchel REJ (1999) Cisplatin-modification of DNA repair and ionizing radiation lethality in yeast, Saccharomyces cerevisiae. Mutat Res 433: 127-36.

25. Fossella FV, Lipmann SC, Shin DM, Arassoff P, Calayag-Jung M, et al. (1997) Maximum-tolerated dose defined for single-agent gemcitabine: a Phase I doseescalation study in chemotherapy-naïve patients with advanced non-small-cell lung cancer. J Clin Oncol 15: 310-316.

26. Manegold C, Zatloukal P, Krejcy K, Blatter J (2000) Gemcitabine in non-small lung cancer (NSCLC). Invest New Drugs 18: 29-42.

27. Castro Kreder N, van Bree C, Franken NA, Haveman J (2004) Effects of gemcitabine on cell survival and chromosome aberrations after pulsed low dose-rate irradiation. J Radiat Res 45: 111-118.

28. Heinemann V, Xu YZ, Chubb S, Sen A, Hertel LW, et al. (1992) Cellular elimination of 2',2'-difluorodeoxycytidine 5'-triphosphate: a mechanism of selfpotentiation. Cancer Res 52: 533-539.

29. Shewach DS, Hahn TM, Chang E, Hertel LW, Lawrence TS (1994). Metabolism of 2',2'-difluoro-2'-deoxycytidine and radiation sensitization of human colon carcinoma cells. Cancer Res 54: 3218-3223.

30. Plunkett W, Huang P, Gandhi V (1995) Preclinical characteristics of gemcitabine. Anti Cancer Drugs 6: 7-13.

31. Auer H, Oehler R, Lindner R, Kowalski H, Sliutz G, et al. (1997) Characterisation of genotoxic properties of 2',2'-difluorodeoxycytidine. Mutat Res 393: 165-173.

32. Rockwell S, Grindey GB (1992) Effect of 2',2'-difluorodeoxycytidine on the viability and radiosensitivity of EMT6 cells in vitro. Oncol Res 4: 151-155.

33. Latz D, Fleckenstein K, Eble M, Blatter J, Wannenmacher M, et al. (1998) Radiosensitizing potential of gemcitabine (2',2'-difluoro-2'-deoxycytidine) within the cell cycle in vitro. Int J Radiat Oncol Biol Phys 41: 875-882.

34. Gregoire V, Hittelman WN, Rosier JF, Milas L (1999) Chemo-radiotherapy: radiosensitizing nucleoside analogues. Oncol Rep 6: 949-957.

35. Mila L, Fujii T, Hunter N, Elshaikh M, Mason K, et al. (1999) Enhancement of tumor radioresponse in vivo by gemcitabine. Cancer Res 59: 107-114.

36. Van Putten JWG, Groen HJM, Smid K, Peters GJ, Kampinga HH (2001) Endjoining deficiency and radiosensitization induced by gemcitabine. Cancer Res 61: 1585-1591.

37. Castro Kreder N, Van Bree C, Franken NA, Haveman J (2003) Colour junctions as predictors of radiosensitivity: $\mathrm{X}$-irradiation combined with gemcitabine in a lung carcinoma cell line. J Cancer Res Clin Oncol 129: 597-603.

38. Scalliet P, Goor C, Galdermans D, Meerbeek J, Groen HJ, et al. (1998) Gemzar (Gemcitabine) with thoracic radiotherapy - a phase II pilot study in chemonaïve patients with advanced non-small-cell lung cancer (NSCLC). Proc Am Soc Clin Oncol 17: A1923.

39. Blackstock AW, Lesser GJ, Fletcher-Steede J, Case LD, Tucker RW, et al. (2001) Phase I Study of twice-weekly gemcitabine and concurrent thoracic radiation for patients with locally advanced son-small cell lung cancer. Int $J$ Radiat Oncol Biol Phys 51: 1281-1289.

40. Van Bree C, Castro Kreder N, Loves WJ, Franken NA, Peters GJ, et al. (2002) Sensitivity to ionizing radiation and chemotherapeutic agents in gemcitabineresistant human tumor cell lines. Int J Radiat Oncol Biol Phys 54: 237-244.

41. Bergman AM, Giaccone G, van Moorsel CJ, Mauritz R, Noordhuis P, et al. (2000) Cross-resistance in the 2',2'-difluorodeoxycytidine (Gemcitabine)resistant human ovarian cancer cell line AG6000 to standard and investigational drugs. Eur J Cancer 36: 1974-1983.
42. Bergman AM, Pinedo HM, Jongsma AP, Brouwer M, Ruiz van Haperen VW, et al. (1999) Decreased resistance to gemcitabine (2',2'-difluorodeoxycitidine) of cytosine arabinoside-resistant myeloblastic murine and rat leukemia cell lines: role of altered activity and substrate specificity of deoxycytidine kinase. Biochem Pharmacol 57: 397-406.

43. Franken NA, van Bree CV, Kipp JB, Barendsen GW (1997) Modification of potentially lethal damage in irradiated chinese hamster V79 cells after incorporation of halogenated pyrimidines. Int J Radiat Biol 72: 101-109.

44. Franken N, Vanbree C, Streefkerk J, Kuper I, Rodermond H, et al. (1997) Radiosensitization by iodo-deoxyuridine in cultured SW-1573 human lung tumor cells. Oncol Rep 4: 1073-1076.

45. Franken NA, Ruurs P, Ludwików G, van Bree C, Kipp JB, et al. (1999) Correlation between cell reproductive death and chromosome aberrations assessed by FISH for low and high doses of radiation and sensitization by iododeoxyuridine in human SW-1573 cells. Int J Radiat Biol 75: 293-299.

46. Franken NA, van Bree C, Veltmaat MA, Ludwików G, Kipp JB, et al. (1999) Increased chromosome frequencies in iodo-doxyuridine-sensitized human SW1573 cells after $\mathrm{Y}$-irradiation. Oncol Rep 6: 59-63.

47. Van Bree C, Franken NA, Bakker PJ, Klomp-Tukker LJ, Barendsen GW et al. (1997) Hyperthermia and incorporation of halogenated pyrimidines: radiosensitization in cultured rodent and human tumor cells. Int J Radiat Onco Biol Phys 39: 489-496

48. Iliakis G, Kurtzman S, Pantelias G, Okayasu R (1989) Mechanism of radiosensitisation by halogenated pyrimidines: Effect of BrdU on radiation induction of DNA and chromosome damage and its correlation with cell killing Radiat Res 119: 286-304.

49. Iliakis G, Wang Y, Pantelias GE, Metzger L (1992) Mechanism of radiosensitisation of halogenated pyrimidines. Effect of BrdU on repair of DNA breaks, interphase chromatin breaks and potentially lethal damage in plateauphase $\mathrm{CHO}$ cells. Radiat Res 129: 202-211.

50. Mille EM, Fowler JF, Kinsella TJ (1992) Linear-quadratic analysis of radiosensitisation by halogenated pyrimidines. I. Radiosensitisation of human colon cancer cells by iododeoxyuridine. Radiat Res 131: 81-89.

51. Miller EM, Fowler JF, Kinsella TJ (1992) Linear-quadratic analysis of radiosensitisation by halogenated pyrimidines. II. Radiosensitisation of human colon cancer cells by bromodeoxyuridine. Radiat Res 131: 90-97.

52. Jones GD, Ward JF, Limoli CL, Moyer DJ, Aguilera JA (1995) Mechanisms of radiosensitization in iododeoxyuridine-substituted cells. Int J Radiat Biol 67: 647-653.

53. Gonzalez Gonzalez D, van Dijk JDP, Blank LECM (1995) Radiotherapy and hyperthermia. Eur J Cancer 31: 1351-1355.

54. Van Der Zee J, Gonzalez Gonzalez D, van Rhoon GC, van Dijk JD, van Putten WL, et al. (2000) Comparison of radiotherapy alone with radiotherapy plus hyperthermia in locally advanced pelvic tumours: a prospective, randomised, multicentre trial. Dutch Deep Hyperthermia Group. Lancet 355: 1119-1125.

55. Van der Zee J, Treurniet-Donker AD, The SK, Helle PA, Seldenrath JJ, et al. (1988) Low dose reirradiation in combination with hyperthermia: a palliative treatment for patients with breast cancer recurring in previously irradiated areas. Int J Radiat Oncol Biol Phys 15: 1407-1413.

56. Van der Zee J, González GD (2002) The Dutch Deep Hyperthermia Trial results in cervical cancer. Int J Hyperthermia 18: 1-12.

57. Crezee J, Barendsen GW, Westermann AM, Hulshof MCCM, Haveman J, et al. (2009) Quantification of the contribution of hyperthermia to results of cervical cancer trials: In regard to Plataniotis and Dale (Int J Radiat Oncol Bill Phys 2009;73:1538-1544). Int J Radiat Oncol Biol Phys 75: 634.

58. Dewey WC, Sapareto SA, Betten DA (1978) Hyperthermic radiosensitization of synchronous Chinese hamster cells: relationship between lethality and chromosomal aberrations. Radiat Res 76: 48-59.

59. Roti Roti JL (2004) Introduction: radiosensitization by hyperthermia. Int $J$ Hyperthermia 20: 109-114.

60. Raaphorst GP, Feeley MM, Danjoux CE, DaSilva V, Gerig LH (1991) Hyperthermia enhancement of radiation response and inhibition of recovery from radiation damage in human glioma cells. Int J Hyperthermia 7: 629-641.

61. Kampinga HH, Dikomey E (2001) Hyperthermic radiosensitization: mode of action and clinical relevance. Int J Radiat Biol 77: 399-408. 
Citation: Franken NAP, Hovingh S, Rodermond H, Stalpers L, Barendsen GW, et al. (2011) Radiosensitization with Chemotherapeutic Agents and Hyperthermia: Effects on Linear-quadratic Parameters of Radiation Cell Survival Curves. J Cancer Sci Ther S5:002. doi:10.4172/19485956.S5-002

Page 10 of 10

62. Hildebrandt B, Wust P, Ahlers O, Dieing A, Sreenivasa G, et al. (2002) The cellular and molecular basis of hyperthermia. Crit Rev Oncol Hematol 43: 3356.

63. Hall EJ, Giaccia AJ (2006) Radiobiology for the Radiobiologist sixth Edition, Lippincott Williams \& Wilkins. Chapter 28, Hyperthermia, pp. 469-490.

64. Dewhirst MW, Vujaskovic Z, Jones E, Thrall D (2005) Re-setting the biologic rationale for thermal therapy. Int J Hyperthermia 21: 779-790.

65. Bergs JW, Haveman J, Ten Cate R, Medema JP, Franken NA, van Bree C (2007) Effect of 41 degrees $C$ and 43 degrees $C$ on cisplatin radiosensitization in two human carcinoma cell lines with different sensitivities for cisplatin. Oncol Rep 18: 219-226

66. Bergs JWJ, Franken NAP, Haveman J, Geijsen ED, Crezee J, et al. (2007) Hyperthermia, cisplatin and radiation trimodality treatment: a promising cancer treatment? A review from preclinical studies to clinical application. Int J Hyperthermia 23: 329-341.

67. Bergs JW, ten Cate R, Haveman J, Medema JP, Franken NA, et al. (2008) Chromosome fragments have the potential to predict hyperthermia-induced radio-sensitization in two different human tumor cell lines. J Radiat Res 49 : $465-472$

68. Krawczyk PM, Eppink B, Essers J, Stap J, Rodermond HM, et al. (2011) Mild hyperthermia inhibits homologous recombination, induces BRCA2 degradation, and sensitizes cancer cells to poly (ADP-ribose) polymerase-1 inhibition. Proc Natl Acad Sci 108: 9851-9856.

69. Franken NA, Ten Cate R, Van Bree C, Haveman J (2004) Induction of the early response protein EGR-1 in human tumour cells after ionizing radiation is correlated with a reduction of repair of lethal lesions and an increase of repair of sublethal lesions. Int J Oncol 24: 1027-1031.

70. Wilkins DE, Ng CE, Raaphorst GP (1996) Cisplatin and low dose rate irradiation in cisplatin resistant and sensitive human glioma cells. Int J Radiat Oncol Bio Phys 36: 105-111.

71. Huang H, Huang, SY, Chen TT, Chen JC, Chiou CL, et al. (2004) Cisplatin restores p53 function and enhances the radiosensitivity in HPV16 E6 containing SiHa cells. J Cell Biochem 91: 756-765.

72. Britten RA, Peacock J, Warenius HM (1992) Collateral resistance to photon and neutron irradiation is associated with acquired cis-platinum resistance in human ovarian tumour cells. Radiother Oncol 23: 170-175.

73. Monk BJ, Burger RA, Parker R, Radany EH, Redpath L, et al. (2002) Development of an in vitro chemo-radiation response assay for cervical carcinoma. Gynecol Oncol 87: 193-199.

74. Britten RA, Evans AJ, Allalunis-Turner MJ, Pearcey RG (1996) Effect of cisplatin on the clinically relevant radiosensitivity of human cervical carcinoma cell lines. Int J Radiat Oncol Biol Phys 34: 367-374

75. Meyn RE, Meistrich ML, White RA (1980) Cycle-dependent anticancer drug cytotoxicity in mammalian cells synchronized by centrifugal elutriation. J Nat Cancer Inst 64: 1215-1219.

76. Krishnaswamy G, Dewey WC (1993) Cisplatin induced cell killing and chromosomal aberrations in $\mathrm{CHO}$ cells: treated during $\mathrm{G} 1$ or $\mathrm{S}$ phase. Mutat Res 293: 161-172.

77. Turchi JJ, Henkels KM, Zhou Y (2000) Cisplatin-DNA adducts inhibit translocation of the Ku subunits of DNA-PK. Nucleic Acids Res 28: 4634-4641.

78. Muggia FM, Fojo T (2004) Platinums: extending their therapeutic spectrum. $J$ Chemother 16: 77-82.

79. DewitL(1987)Combined treatment of radiationand cisdiamminedichloroplatinum (II): a review of experimental and clinical data. Int J Radiat Oncol Biol Phys 13: $403-426$

80. Kumala S, Niemiec P, Widel M, Hancock R, Rzeszowska-Wolny J (2003) Apoptosis and clonogenic survival in three tumour cell lines exposed to gamma rays or chemical genotoxic agents. Cell Mol Biol Lett 8: 655-665.

81. Guchelaar HJ, Vermes I, Koopmans RP, Reutelingsperger CP, Haanen C (1998) Apoptosis- and necrosis-inducing potential of cladribine, cytarabine, cisplatin, and 5-fluorouracil in vitro: a quantitative pharmacodynamic model. Cancer Chemother Pharmacol 42: 77-83.

82. Fujita M, Fujita T, Kodama T, Tsuchida T, Higashino K (2000) The inhibitory effect of cisplatin in combination with irradiation on lung tumor cell growth is due to induction of tumor cell apoptosis. Int J Oncol 17: 393-397.

83. Ostruszka LJ, Shewach DS (2000) The role of cell cycle progression in radiosensitization by 2',2'-difluoro-2'-deoxycytidine. Cancer Res 60: 60806088.

84. Ruiz van Haperen VW, Veerman G, Eriksson S, Boven E, Stegmann AP, et al. (1994) Development and molecular characterization of a 2',2'-difluorodeoxycytidine-resistant variant of the human ovarian carcinoma cell line A2780. Cancer Res 54: 4138-4143.

85. Peters GJ, Ruiz van Haperen VW, Bergman AM, Veerman G, SmitskampWilms E, et al. (1996) Preclinical combination therapy with gemcitabine and mechanisms of resistance. Semin Oncol 23: 16-24.

86. Wang Y, Pantelias GE, lliakis G (1994) Mechanism of radiosensitization by halogen ated pyrimidines: the contribution of excess DNA and chromosome damage in BrdU radiosensitization may be minimal in plateau cells. Int J Radiat Biol 66: 133-142.

87. Webb CF, Jones GD, Ward JF, Moyer DJ, Aguilera JA, et al. (1993) Mechanisms of radiosensitisation in bromodeoxyuridine-substituted cells. Int J Radiat Biol 64: 695-705.

88. Ryu S, Brown SL, Kim SH, Khil MS, Kim JH (1996) Preferential radiosensitization of human prostatic carcinoma cells by mild hyperthermia. Int $J$ Radiat Oncol Biol Phys 34: 133-138.

89. Franken NA, Van Bree C, Veltmaat MA, Rodermond HM, Haveman J, et al. (2001) Radiosensitization by bromodeoxyuridine and hyperthermia: analysis of linear and quadratic parameters of radiation survival curves of two human tumor cell lines. J Radiat Res 42: 179-190.

90. Larsson C, Ng CE (2003) p21+/+ (CDKN1A+/+) and p21-/- (CDKN1A-/-) human colorectal carcinoma cells display equivalent amounts of thermal radiosensitization. Radiat Res 160: 205-209.

91. Murthy AK, Harris JR, Belli JA (1977) Hyperthermia and radiation response of plateau phase cells. Potentiation and radiation damage repair. Radiat Res 70 241-247.

92. Van Bree C, van Der Maat B, Ceha HM, Franken NAP, Haveman J, et al. (1992) Inactivation of p53 and of pRb protects human colorectal carcinoma cells against hyperthermia-induced cytotoxicity and apoptosis. J Cancer Res Clin Oncol 125: 549-555.

93. Van Bree C, Savonije JH, Franken NA, Haveman J, Bakker PJ (2000) The effec of p53-function on the sensitivity to paclitaxel with or without hyperthermia in human colorectal carcinoma cells. Int J Oncol 16: 739-744.

94. Xu M, Wright WD, Higashikubo R, Wang LL, Roti Roti JL (1999) Thermal radiosensitization of human tumour cell lines with different sensitivities to 41 . degrees C. Int J Hyperthermia 15: 279-290.

95. Xu M, Myerson RJ, Straube WL, Moros EG, Lagroye I, et al. (2002) Radiosensitization of heat resistant human tumour cells by 1 hour at 41.1 degrees $\mathrm{C}$ and its effect on DNA repair. Int J Hyperthermia 18: 385-403.

96. Vujaskovic Z, Song CW (2004) Physiological mechanisms underlying heatinduced radiosensitization. Int J Hyperthermia 20: 163-174.

97. Oleson JR (1995) Eugene Robertson Special Lecture. Hyperthermia from the clinic to the laboratory: a hypothesis. Int J Hyperthermia 11: 315-322.

98. Song CW, Shakil A, Osborn JL, Iwata K (1996) Tumour oxygenation is increased by hyperthermia at mild temperatures. Int $\mathrm{J}$ Hyperthermia 12: 367 373.

99. Bergs JW, Krawczyk PM, Ten Cate R, Rodermond HM, Borovski T, et al (2010) Inhibition of homologous recombination by mild hyperthermia shunts early double strand break repair to non-homologous end-joining in $\mathrm{G} 2$ phase cells. Int J Mol Medic 26: S10-S123.

100.Xu M, Myerson RJ, Xia Y, Whitehead T, Moros EG, et al. (2007) The effects of 41 degrees $C$ hyperthermia on the DNA repair protein, MRE11, correlate with radiosensitization in four human tumor cell lines. Int J Hyperthermia 23 343-351

101. Mackey MA, lanzini F (2000) Enhancement of radiation-induced mitotic catastrophe by moderate hyperthermia. Int J Radiat Biol 76: 273-280. 